\title{
A Multifunctional Solution for Simultaneous Sound Insulation and Acoustic Conditioning-An Example of Application in a Radio Studio
}

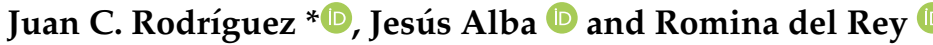

check for updates

Citation: Rodríguez, J.C.; Alba, J.; del Rey, R. A Multifunctional Solution for Simultaneous Sound Insulation and Acoustic Conditioning-An Example of Application in a Radio Studio. Buildings 2022, 12, 123. https:// doi.org/10.3390/buildings12020123

Academic Editor: Francesco Nocera

Received: 27 December 2021

Accepted: 23 January 2022

Published: 26 January 2022

Publisher's Note: MDPI stays neutral with regard to jurisdictional claims in published maps and institutional affiliations.

Copyright: (C) 2022 by the authors. Licensee MDPI, Basel, Switzerland. This article is an open access article distributed under the terms and conditions of the Creative Commons Attribution (CC BY) license (https:// creativecommons.org/licenses/by/ $4.0 /)$
Centro de Tecnologías Físicas, Universitat Politècnica de València, 46730 Valencia, Grao de Gandia, Spain; jesalba@fis.upv.es (J.A.); roderey@fis.upv.es (R.d.R.)

* Correspondence: juarodve@upv.es

\begin{abstract}
In building acoustics, two different problems usually arise. There is a need to comply with established sound insulation parameters, but there are also legislative conditions concerning reverberation time. It is therefore necessary to acoustically insulate and condition the enclosures. When designing the acoustic treatment of buildings, sound insulation is always considered before acoustic conditioning. There are multiple solutions for sound insulation; one of them consists of a base wall reinforced with a plasterboard lining. The sound insulation improvement provided by these solutions will depend on the type of base wall used. A common solution for acoustic conditioning is the use of perforated plate lining systems with a plenum filled with sound absorbing material. This work presents a solution for simultaneous sound insulation and conditioning improvement, reducing the installation costs. Materials that provide the acoustic conditioning features were analyzed to validate their use in the complete solution, performing airflow resistance tests. The complete solution was also evaluated on a laboratory scale by conducting tests in a reverberation chamber and in a transmission chamber for small samples. Finally, the effectiveness of the presented solution was assessed with in-situ tests in a radio studio.
\end{abstract}

Keywords: sound insulation; acoustic conditioning; multilayer solutions; perforated plasterboard lining

\section{Introduction}

When acoustically designing a space, essentially, two requirements must be met to guarantee acoustic comfort; these are good sound insulation and controlled reverberation time. These conditions will provide a quiet or low-noise space and good listening conditions whether for talking, listening to music or any other type of sound reproduction. Some examples of the increasing relevance of acoustic comfort in homes and offices can be found in the literature [1-5].

These requirements are usually met using two independent solutions, one for sound insulation and another for acoustic conditioning. This work presents the study of a solution that meets both requirements simultaneously with materials available in the market, which considerably reduces production and installation costs.

In the near future, alternative solutions designed with metamaterials that also address both problems simultaneously are foreseeable, even with improved performance in the low frequency range; however, for the time being these solutions require a degree of custom design and fabrication that still make them quite expensive for widespread use in buildings. Some reviews that can serve as an introduction to the topic can be found in $[6,7]$.

The proposed solution consists of a plasterboard lining system formed by a viscoelastic multilayer-composed of two layers of textile felt with the same density and thickness, thermally adhered to a high-density viscoelastic membrane-combined with perforated plasterboard. This solution requires a base wall. Combining the viscoelastic membrane with the textile should provide the solution with airborne sound insulation characteristics. The 
closure with perforated plasterboards over the textile felt layer should efficiently control the reverberation time.

The use of viscoelastic membranes is a common practice in sound insulation applications $[8,9]$, and their positive performance in these cases has already been demonstrated. Combining this material with a porous layer can also provide excellent sound absorbing behavior.

In buildings, this porous sound absorbing layer usually consists of fibers or foams. In this case, a textile felt created from waste from the textile industry was used as the porous sound absorbing layer. The textile industry generates an enormous quantity of residues, so recycling them is crucial. An example of using these residues for other applications embracing circularity is their use in acoustic conditioning solutions as sustainable sound absorbers [10-12].

However, the use of sustainable materials in acoustic treatments is not only limited to recycled textiles and their sound absorption applications. The growing importance of using environmentally friendly materials in buildings has given rise to a great deal of research on different materials and their applications for sound insulation and acoustic conditioning [13-19]. Besides the environmental benefits, using these materials usually reduces production costs since they come from natural or recycled materials.

The textile felt provides part of the sound absorption of the proposed solution and also helps to improve the sound insulation but it cannot be left exposed, so another layer that does not penalize the global sound absorption is needed. This may lead to considering combining the existing elements with a final layer of perforated plasterboard to obtain a ready-to-install solution, as presented in Figure 1.

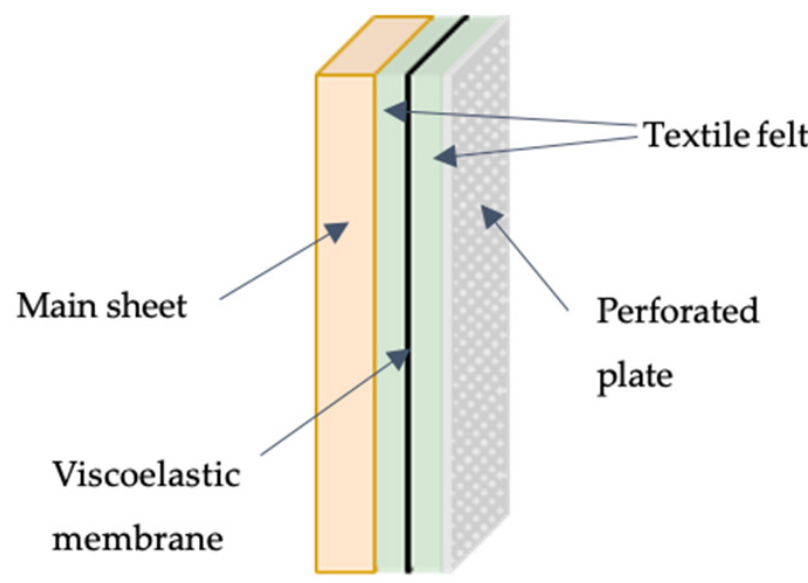

Figure 1. Overview of the proposed solution.

The perforated plasterboard helps to slightly increase the low frequency sound absorption and to tune the solution to achieve the most absorption in the range of mid frequencies of interest in each case. Some recent examples of using perforated plates to control sound absorption can be found in $[20,21]$.

The sound insulation improvement provided by the proposed lining system will depend on the base wall used. The final sound absorption will depend on the type of perforated plasterboard and the plenum left between the plasterboard lining and the base wall. Therefore, by adjusting its different elements the proposed solution can be helpful in applications where controlled sound absorption levels are needed while maintaining optimum sound insulation behavior.

This work assesses the behavior of different configurations for the proposed solution, combining the viscoelastic multilayer with varying types of perforated plasterboard. Sound absorption and sound transmission tests were carried out for each analyzed configuration. 
Finally, the effectiveness of the presented solution was assessed with in-situ tests in a couple of enclosures destined to function as a radio studio, which required both types of acoustic treatments. The proposed solution is validated with the obtained results in the in-situ installations.

\section{Materials}

This section describes the most relevant characteristics of each of the elements that make up the multi-functional solution. The proposed solution consists of a plasterboard lining system formed by a viscoelastic multilayer-composed of two layers of textile felt with the same density and thickness, thermally adhered to a high-density viscoelastic membrane forming a sandwich—combined with perforated plasterboard. First, the characteristics of the viscoelastic multilayer as a solution for sound insulation in conjunction with the base wall are presented, including the airflow resistivity in the case of the textile felts. Subsequently, the characteristics of the perforated plates, which allow the effective control of the reverberation time, are described.

\subsection{The Textile Felt}

The viscoelastic multilayer used in the proposed solution, as shown in Figure 1, contains two $16 \mathrm{~mm}$-thick layers of textile felt (FLT) with a mass density of $928 \mathrm{~g} / \mathrm{m}^{2}$. This material is formed by recycled textile fibers that come from waste from the textile industry. Some photographs of the material can be seen in Figure 2.
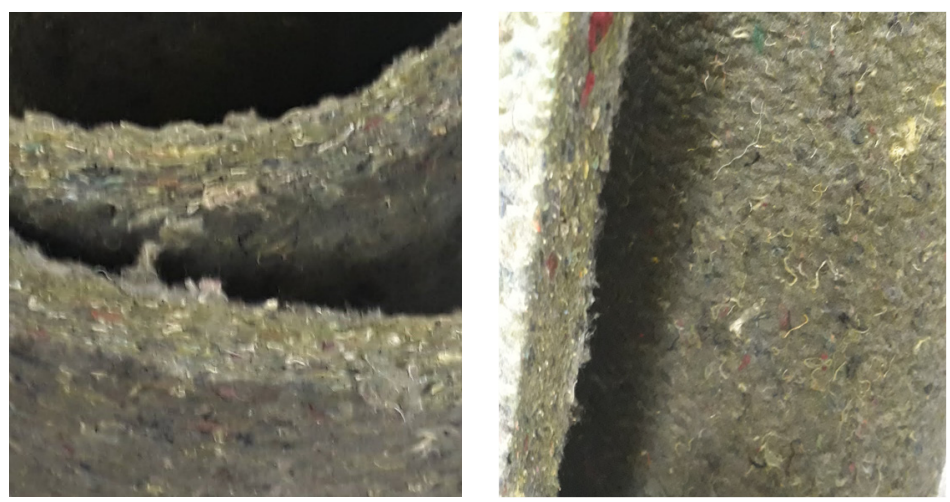

Figure 2. Materials: the textile felt (FLT).

To validate its acoustic performance, the first step was to check if the porous material was optimal for acoustic solutions. In Appendix D of the ISO 12354-1 [22]—used to obtain the sound reduction index improvement of additional layers-a requirement of a minimum airflow resistivity of $5 \mathrm{kPa} \cdot \mathrm{s} / \mathrm{m}^{2}$ for the porous material filling the cavity is set, so the first step was to validate this requirement.

\section{Airflow Resistivity of the Textile Felt}

Airflow resistivity is one of the main non-acoustic parameters used to characterize the sound absorption properties of a porous material. It is used in practice for selecting appropriate materials for noise control and building acoustic applications.

Several organizations, including ISO and ASTM, described the standardized laboratory procedures for measuring airflow resistivity, specifically through standards ISO 9053-1 [23], ISO 9053-2 [24] and ASTM C522-03 [25]. Implementation of these standardized procedures requires rather complex and unusual instrumentation in acoustic laboratories, and it is also necessary to measure sound pressures at a very low frequency. These facts led to the development and use of alternative methods to measure airflow resistivity. Some discussion about some of them can be found in the literature [26-35].

In this work, flow resistance tests were carried out following the procedure described by one of these alternative methods to the standards: the Ingard and Dear method [27]. 
Three circular samples of $41 \mathrm{~mm}$ were measured in an Ingard and Dear tube, and the final results were obtained by calculating the arithmetic mean of the three. The tests yielded a value of $11.1 \pm 0.8 \mathrm{kPa} \cdot \mathrm{s} / \mathrm{m}^{2}$, which is over the minimum limit of $5 \mathrm{kPa} \cdot \mathrm{s} / \mathrm{m}^{2}$ required in Appendix D of the ISO 12354-1, validating the material for its use inside the plasterboard lining system plenum.

\subsection{The Viscoelastic Membrane}

The other element that conforms to the viscoelastic multilayer is a 4 mm-thick highdensity $\left(12.8 \mathrm{~kg} / \mathrm{m}^{2}\right)$ viscoelastic membrane, as shown in Figure 3. The composition of the membrane, as described by the manufacturer, is:

- $\quad$ Elastomeric bitumen: asphalt bitumen modified with SBS elastomeric rubber.

- Filler: ground calcium carbonate.

- Armor: fiberglass felt.

- Anti-stick: hot-melt polystyrene film.
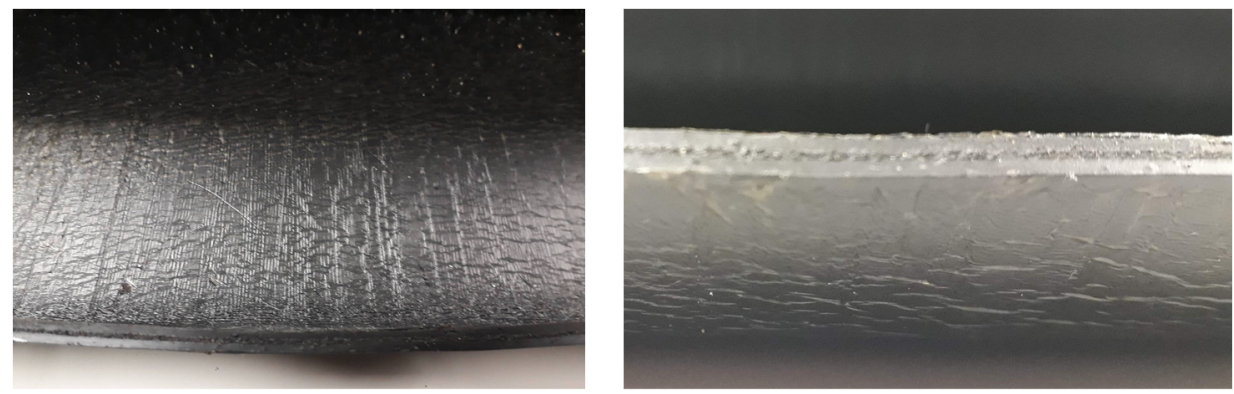

Figure 3. Materials: the viscoelastic membrane.

\subsection{The Viscoelastic Multilayer (VLM)}

The viscoelastic multilayer (VLM) consists of three layers of the previously described materials, forming a sandwich of two layers of the textile felt thermally adhered to the high-density viscoelastic membrane. It has a total thickness of $36 \mathrm{~mm}$ and a mass density of $8.4 \mathrm{~kg} / \mathrm{m}^{2}$. Details of the viscoelastic multilayer can be seen in Figure 4.
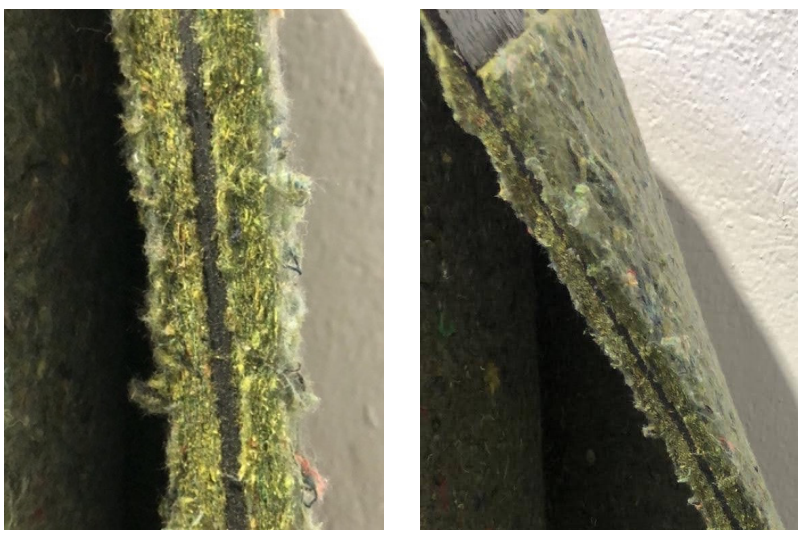

Figure 4. Details of the viscoelastic multilayer.

\subsection{The Perforated Plates}

Four different perforated plasterboards were used to form four different configurations, each with different sound reduction and sound absorption properties.

The plates have different aesthetics (perforation rates, sizes and shapes). Three of them have circular perforations and the fourth squared ones, all of which have a range of perforation rates from $8 \%$ to $18 \%$ and mass densities between 8 and $12 \mathrm{~kg} / \mathrm{m}^{2}$. The 
properties of each type of perforated plasterboard, presented in Figure 5, are detailed in Table 1.

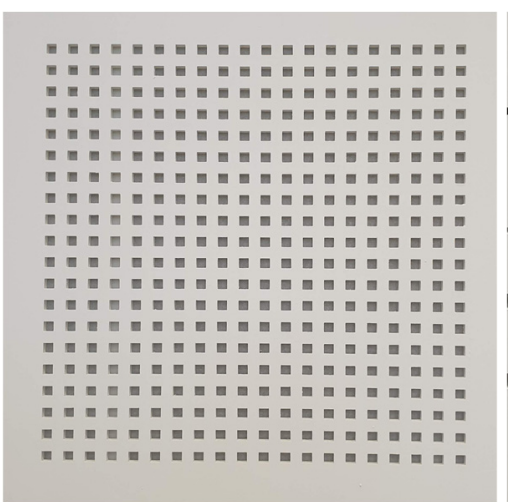

(a)

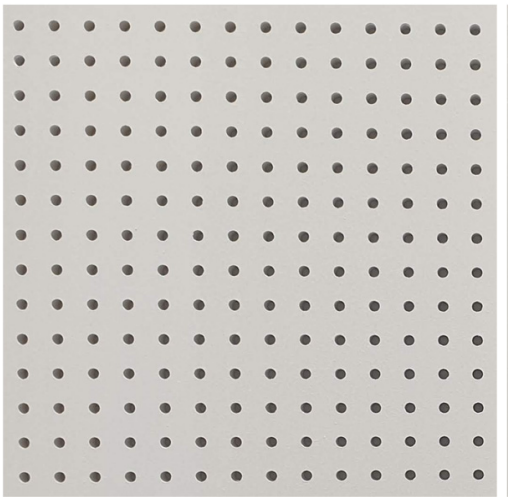

(c)

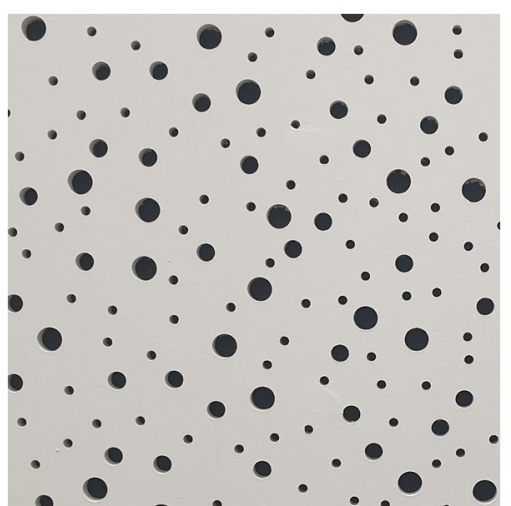

(b)

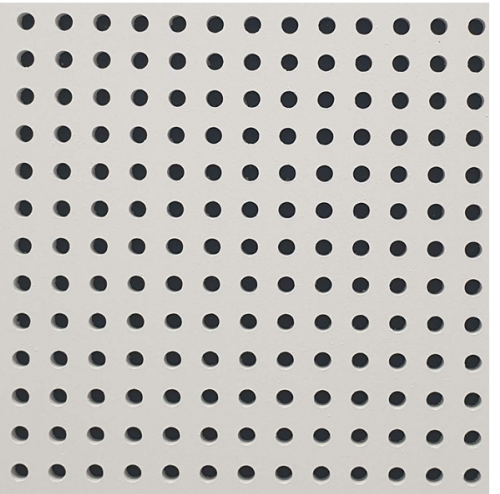

(d)

Figure 5. Detail of the perforated plates: (a) PRF1; (b) PRF2; (c) PRF3; (d) PRF4.

Table 1. Properties of the perforated plasterboards.

\begin{tabular}{cccccc}
\hline $\begin{array}{c}\text { Perforated } \\
\text { Plate }\end{array}$ & $\begin{array}{c}\text { Thickness } \\
(\mathbf{m m})\end{array}$ & $\begin{array}{c}\text { Perf. } \\
\text { Shape }\end{array}$ & $\begin{array}{c}\text { Perforation } \\
\text { Rate } \\
\mathbf{( \% )}\end{array}$ & $\begin{array}{c}\text { Perforation } \\
\text { Size } \\
\mathbf{( m m})\end{array}$ & $\begin{array}{c}\text { Mass } \\
\text { Density } \\
\mathbf{( k g / \mathbf { m } ^ { 2 } )}\end{array}$ \\
\hline PRF1 & 12.5 & Squared & 16 & $12 \times 12$ & 8 \\
PRF2 & 12.5 & Circular & 10 & $8,15,20$ & 10 \\
PRF3 & 12.5 & Circular & 9 & 6 & 9 \\
PRF4 & 12.5 & Circular & 18 & 12 & 8 \\
\hline
\end{tabular}

\section{Assessment of the Acoustic Behavior of the Proposed Solution}

Different tests were conducted to assess the acoustic behavior of the proposed multifunctional solution, designed to provide sound insulation and acoustic conditioning improvements.

Four different plasterboard lining system configurations were assessed, one with each perforated plasterboard described in Table 1, combined with the viscoelastic multilayer.

Sound transmission tests were carried out in a reduced size transmission chamber for small samples to determine the characteristics of the four proposed configurations as solutions for sound insulation. In addition, an estimation of the airborne noise improvement provided by this solution was carried out based on the guidelines of Annex D of the ISO 12354-1 standard.

To assess the suitability of the proposed solution for acoustic conditioning, sound absorption tests in diffuse field conditions were also carried out for each configuration. These tests were carried out in a reverberation chamber. 


\subsection{Validation of the Proposed Solution for Sound Insulation}

3.1.1. Sound Reduction Index, $\mathrm{R}(\mathrm{dB})$

To estimate the sound insulation properties of the presented solution, the sound reduction index, $\mathrm{R}(\mathrm{dB})$, of the four proposed configurations was assessed.

The entire ISO 10140 standard is related to the laboratory measurement of sound insulation of building elements. The ISO 10140-2 standard [36] in particular indicates the procedure for the measurement of sound insulation to airborne noise in compliance with the ISO 10140-4 [37] and the ISO 10140-5 [38] standards.

Since a normalized transmission chamber as described in the ISO-10140-5 standard was not available in the Escola Politècnica Superior de Gandia (EPSG) laboratories, a reduced size transmission chamber that reproduces the geometry of standard transmission chambers to scale was used. The design of this chamber was carried out according to the ISO 10140-5 standard, following a similar approach as described in [39]. The details of the design and building process of the chamber are presented in [40], where this chamber was used to evaluate the performance of new sustainable solutions for sound insulation. Some images of the setup for the tests are presented in Figure 6, where the chamber during one of the tests and the detail of the mounting of one of the proposed configurations in the sample holder can be seen. As can be observed, no studs were used during these tests, so the results should not be compared with usual double-leaf plasterboard systems, and should only be used to compare the proposed configurations.

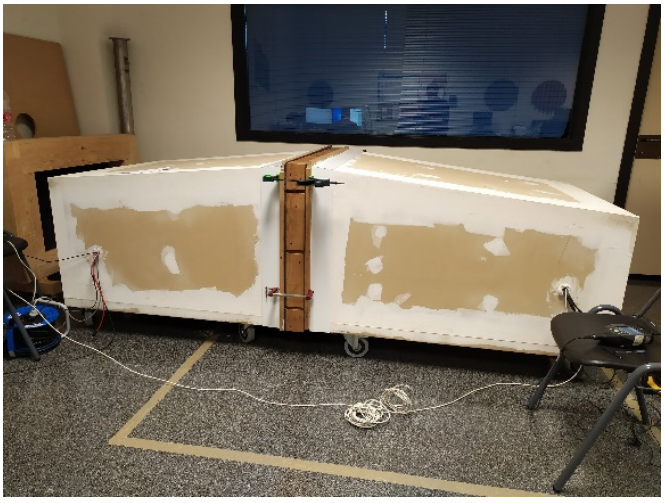

(a)

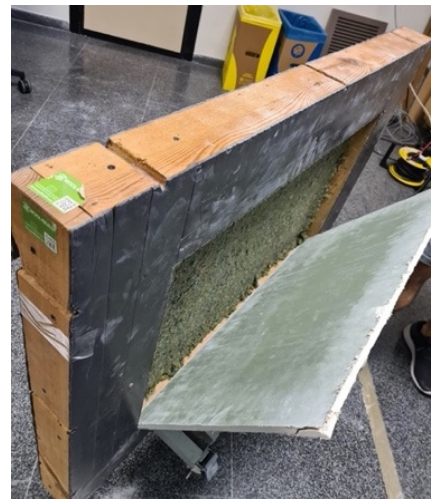

(b)

Figure 6. Setup for the sound transmission tests: (a) the transmission chamber during one of the tests; (b) detail of one of the tested configurations placed in the sample holder.

A total of six configurations were assessed in the reduced size transmission chamber (Table 2). Each tested configuration consisted of a combination of some of these materials: non-perforated plasterboards (PB), the viscoelastic multilayer (VLM), the textile felt (FLT) and one of the perforated plasterboards (PRFx).

Table 2. Test configurations for the sound reduction index tests.

\begin{tabular}{cc}
\hline Test Configuration & Description \\
\hline 1 & PB + FLT + PB \\
2 & PB + VLM + PB \\
3 & PB + VLM + PRF1 \\
4 & PB + VLM + PRF2 \\
5 & PB + VLM + PRF3 \\
6 & PB + VLM + PRF4 \\
\hline
\end{tabular}

Besides the initial four proposed configurations formed by a non-perforated plasterboard, the viscoelastic multilayer and each of the perforated plasterboards, two addi- 
tional configurations were tested to have further information to compare: one consisting of a sandwich of two non-perforated plasterboards and one layer of the textile felt, and a second one consisting of a sandwich of two non-perforated plasterboards and the viscoelastic multilayer.

The results of each test are presented graphically in Figure 7. The sandwich configurations with the non-perforated plasterboards mark the upper and lower limits for the sound reduction index. In the case of the configurations with perforated plates, as expected, those using plasterboards with higher density and lower perforation rate are the ones with better performance for sound insulation.

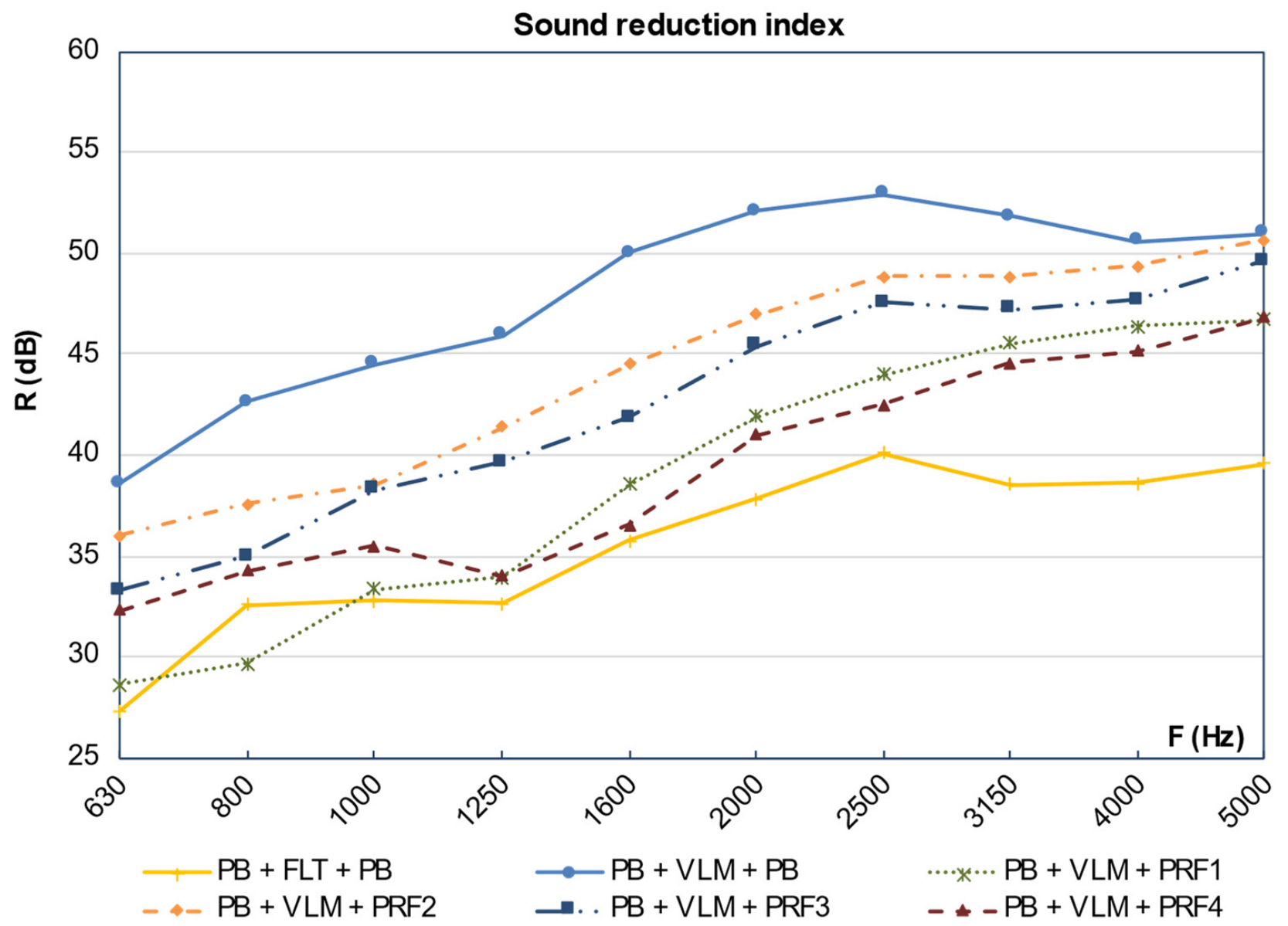

Figure 7. Sound reduction index, $\mathrm{R}(\mathrm{dB})$, of the assessed configurations.

\subsubsection{Estimation of the Airborne Sound Insulation}

One of the main objectives of the proposed solution is to provide good levels of noise reduction improvement. Appendix D of the ISO 12354-1 standard [22] defines a procedure to estimate the sound reduction index improvement of additional layers $\left(\Delta \mathrm{R}_{\mathrm{A}}\right)$. These estimations are similar to the one proposed in the basic document for noise protection (DB-HR) [41], part of the Spanish Technical Building Code [42] published by the Spanish government.

This section presents a prediction of the airborne sound insulation provided by the proposed solution. This prediction was obtained according to the ISO 12354-1 standard guidelines, starting from the estimated resonance frequency of the proposed solution. The different assembly elements are adjusted as far as possible until a value for its resonance frequency is obtained within the target range to improve sound insulation. 
To make these estimates, we start from the main sheet of mass $m_{1}$ and a lining system with absorbent material of thickness $d$ and a plate of mass $m_{2}$ (see Figure 1). The resonant frequency, $f_{0}$, is calculated according to Equation (1):

$$
f_{0}=\frac{1000}{2 \pi} \sqrt{\frac{0.111}{d}\left(\frac{1}{m_{1}}+\frac{1}{m_{2}}\right)}
$$

This resonant frequency, $f_{0}$, is the main control parameter for the system's design. It is valid as long as the airflow resistivity is higher than $5 \mathrm{kPa} \cdot \mathrm{s} / \mathrm{m}^{2}$.

Since the main objective is that the proposed solution provides both sound absorption and sound insulation, the assembly can be divided as follows: the main wall with the first textile felt and the viscoelastic membrane would be in charge of the sound insulation improvement, in the most conservative case, and the second textile felt with the perforated panel (which must have the corresponding veil) would provide the sound absorption improvement part.

Considering the viscoelastic layer of mass $m_{2}=6.8 \mathrm{~kg} / \mathrm{m}^{2}$ and the $16 \mathrm{~mm}$ thick textile felt with an airflow resistivity of $11.1 \mathrm{kPa} \cdot \mathrm{s} / \mathrm{m}^{2}$, Equation (1) must introduce masses of $70 \mathrm{~kg} / \mathrm{m}^{2}$ upwards for the main sheet, which are much higher than the mass of the viscoelastic layer. This means that Equation (1) can be simplified and gives a fixed value:

$$
f_{0} \approx 53 \sqrt{\frac{1}{d \cdot m_{2}}}
$$

To achieve an improvement in airborne sound insulation, $f_{0}$ must be less than $200 \mathrm{~Hz}$ (or not within the $200 \mathrm{~Hz}$ band). For the case under study, applying the available data of each of the materials, the resonance frequency, $f_{0}$, is in the range of 161 to $177 \mathrm{~Hz}$, considering a margin between 14-16 mm of the textile felt (since it is known that its thickness can be reduced due to material manipulation). If Table D.1 of the ISO 12354-1 standard is applied, taking into account that $f_{0}$ is rounded to the third-octave band to which it belongs (in this case, $160 \mathrm{~Hz}$, whose band is from 143 to $180 \mathrm{~Hz}$ ), an improvement in the acoustic reduction index can be obtained using a lining, assuming metal or wooden studs or slats are not directly connected to the primary structural element.

Applying the standard with a $2 \mathrm{~dB}$ security correction, we obtained the improvement of the sound reduction index presented in Table 3.

Table 3. Theoretical estimation of the sound reduction index improvement of additional layers.

\begin{tabular}{cccccccccc}
\hline Main sheet $\left(\mathbf{k g} / \mathbf{m}^{\mathbf{2}}\right)$ & 70 & 100 & 140 & 160 & 180 & 200 & 250 & 300 & 350 \\
\hline$\Delta \mathbf{R}_{\mathbf{A}} \mathbf{( d B )}$ & 10 & 9 & 8 & 7 & 6 & 5 & 3 & 2 & 1 \\
\hline
\end{tabular}

For these estimates to be correct, the following conditions must be met:

- There must be continuity in the viscoelastic membrane.

- The thickness of the textile felt should be kept between 14-16 mm, with a gap of 4-5 mm between the material and the main sheet.

The effect of the textile felt and the veil with the perforations of the plasterboard will also be positive, but it is difficult to quantify it. However, if the perforation rate is too high, this improvement could also decrease.

An estimation of the sound reduction index improvement of additional layers from experimental data is presented in Table 4. 
Table 4. Estimation of the sound reduction index improvement of additional layers, $\Delta R_{A}(d B)$, from experimental data.

\begin{tabular}{|c|c|c|c|c|c|c|c|c|c|c|c|c|}
\hline $\begin{array}{r}\text { Mai } \\
\text { (k }\end{array}$ & $\begin{array}{l}\text { heet } \\
\left.\mathrm{l}^{2}\right)\end{array}$ & 70 & 100 & 140 & 160 & 180 & 200 & 250 & 300 & 350 & 400 & 500 \\
\hline \multirow{5}{*}{$\begin{array}{l}\Delta R_{A} \\
(\mathrm{~dB})\end{array}$} & $\mathrm{PB}$ & 14 & 13 & 12 & 11 & 10 & 9 & 7 & 6 & 5 & 4 & 2 \\
\hline & PRF1 & 3 & 2 & 1 & - & - & - & - & - & - & - & - \\
\hline & PRF2 & 8 & 7 & 6 & 5 & 4 & 3 & 1 & - & - & - & - \\
\hline & PRF3 & 8 & 7 & 6 & 5 & 4 & 3 & 1 & - & - & - & - \\
\hline & PRF4 & 6 & 5 & 4 & 3 & 2 & 1 & - & - & - & - & - \\
\hline
\end{tabular}

It must be taken into account that the assembly for these measurements did not follow the usual installation procedure since no studs or slats were used. They were carried out just to compare the behavior of the different perforated plates. It is expected that in normal installation conditions, these levels of improvement could be higher.

\subsection{Validation of the Proposed Solution for Acoustic Conditioning}

To validate the presented solution as an effective solution for reverberation time control, the sound absorption of the proposed solution in diffuse field conditions was evaluated.

Sound Absorption of the Complete Solution in Diffuse Field Conditions

The sound absorbing performance of the proposed solution was assessed with the four perforated plasterboards, the main properties of which are described in Table 1. An additional test was carried out without any perforated plate over the viscoelastic multilayer.

These tests were conducted following the ISO 354 standard [43]. Other standards such as the ISO 11654 [44] and the ASTM C423 [45] were also used to obtain additional results. The former considers the parameter $\alpha_{\mathrm{w}}$, which is a weighted version of the absorption coefficient that allows representation of the absorption of a material with a unique value; the latter includes the $80 \mathrm{~Hz}$ band in the evaluated frequency range and also considers the parameters "sound absorption average" (SAA) and "noise reduction coefficient" (NRC).

In this case, the tests were carried out in the standard reverberation chamber of the Escola Politècnica Superior de Gandia, which has a volume of $238 \mathrm{~m}^{2}$ and a total surface area of $236 \mathrm{~m}^{2}$. The surface area of the assessed configurations was $11.4 \mathrm{~m}^{2}$. Some images from the tests are presented in Figure 8.
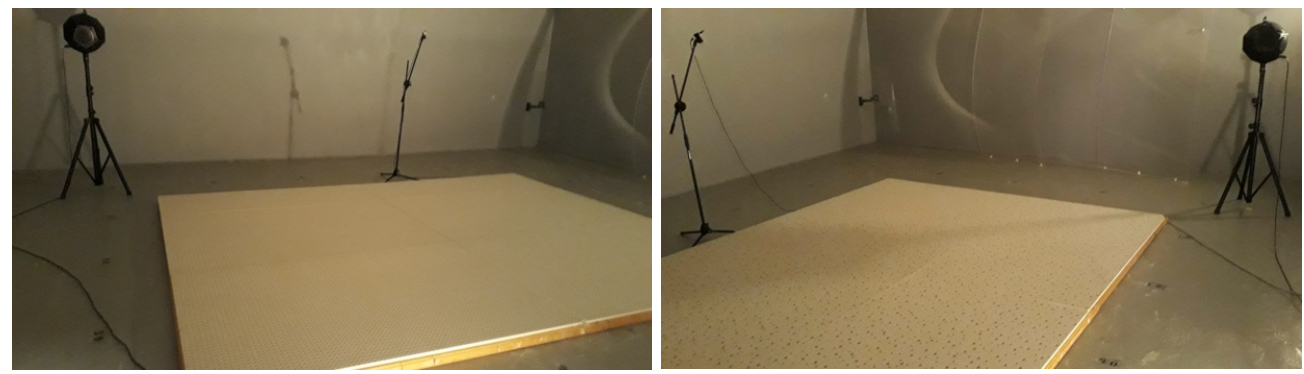

Figure 8. Sound absorption tests in the reverberation chamber of the EPSG-UPV.

Figure 9 shows the results of the sound absorption coefficient of the assessed configurations in one-third of octave bands, and Tables 5 and 6 show the overall values according to standards ISO 11654 and ASTM C423, respectively. 


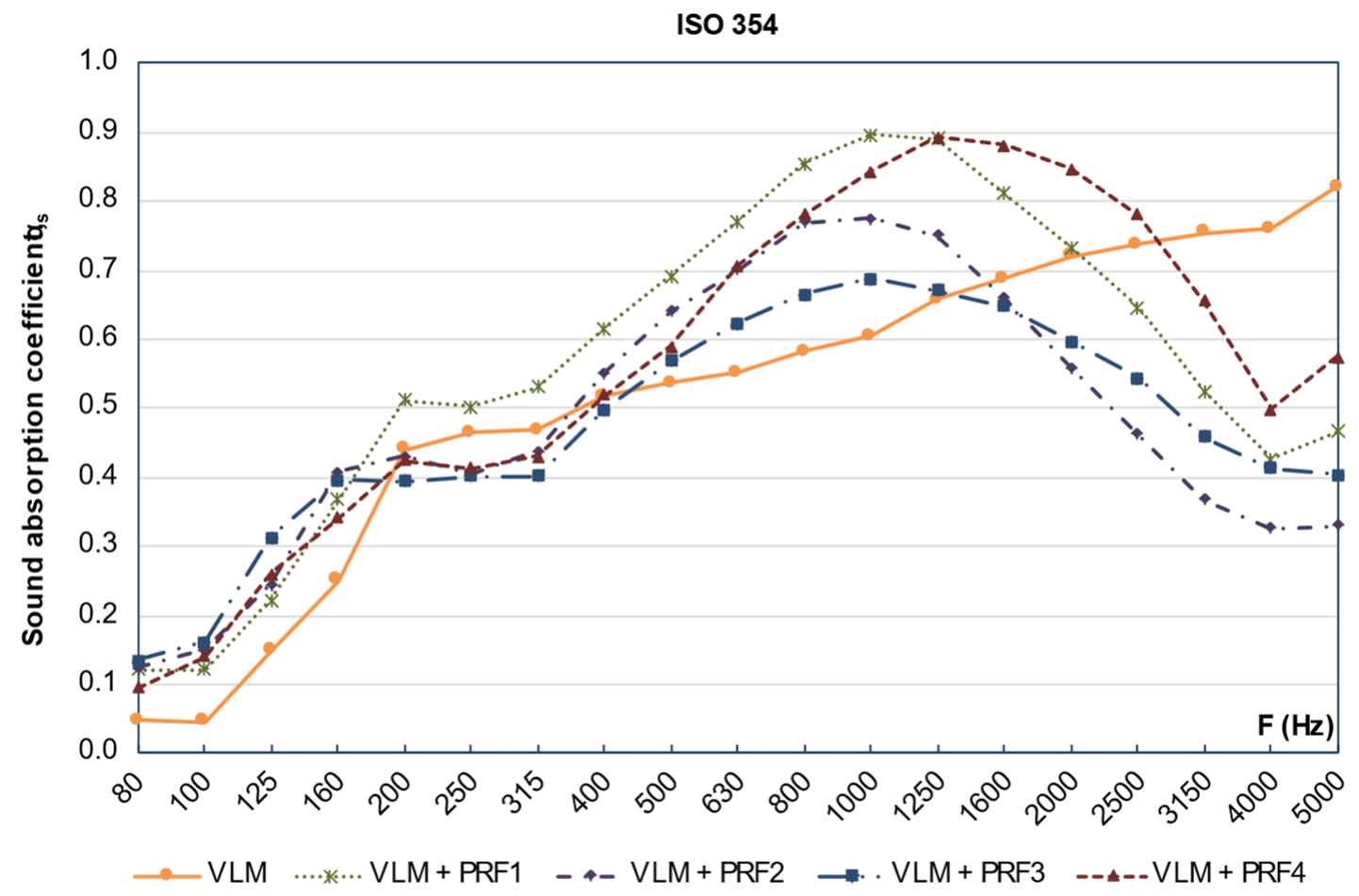

Figure 9. ISO 354 results for the assessed configurations.

Table 5. UNE-EN ISO 11654 results and classification.

\begin{tabular}{cccccc}
\hline & \multirow{2}{*}{ VLM } & VLM + & VLM + & VLM + & VLM + \\
& PRF1 & PRF2 & PRF3 & PRF4 \\
\hline$\alpha_{\mathrm{W}}$ & $0.60(\mathrm{H})$ & 0.65 & 0.55 & 0.55 & 0.65 \\
CLASS & $\mathrm{C}$ & $\mathrm{C}$ & $\mathrm{D}$ & $\mathrm{D}$ & $\mathrm{C}$ \\
\hline
\end{tabular}

Table 6. ASTM C423 results.

\begin{tabular}{cccccc}
\hline & VLM & $\begin{array}{c}\text { VLM + } \\
\text { PRF1 }\end{array}$ & $\begin{array}{c}\text { VLM + } \\
\text { PRF2 }\end{array}$ & $\begin{array}{c}\text { VLM + } \\
\text { PRF3 }\end{array}$ & $\begin{array}{c}\text { VLM + } \\
\text { PRF4 }\end{array}$ \\
\hline NRC & 0.60 & 0.70 & 0.60 & 0.55 & 0.70 \\
SAA & 0.58 & 0.70 & 0.60 & 0.56 & 0.68 \\
\hline
\end{tabular}

As expected, the perforated plasterboards with higher perforation rates yield higher values for the sound absorption coefficient. It can also be seen that the absorption curve can also be tunned with the perforations of the plasterboards, but this is not the objective of this work.

\section{An Example Application: A Radio Studio}

To validate the proposed solution in a real scenario, an installation in a couple of enclosures destined to function as a radio studio was carried out. The enclosures are located on the top floor of one of the Escola Politècnica Superior de Gandia buildings. Figure 10 shows the building plan with the location of each room. 


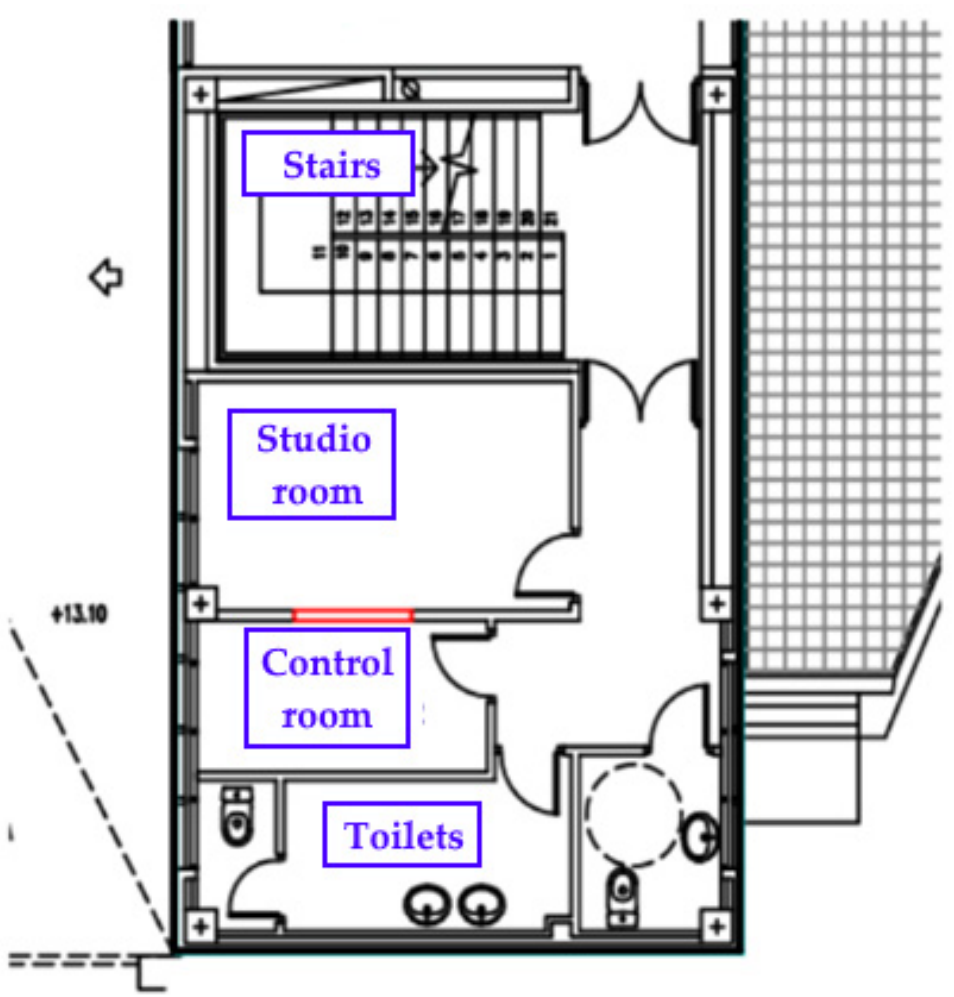

Figure 10. Building floor plans with the enclosures under study.

As observed in the building plan, the location and the characteristics of the enclosures are not favorable for a radio studio, as both of them are very small and are surrounded by common areas. The dimensions of the rooms are presented in Table 7.

Table 7. Dimensions of the enclosures.

\begin{tabular}{cccc}
\hline Enclosure & $\begin{array}{c}\text { Volume } \\
\left(\mathbf{m}^{\mathbf{3}}\right)\end{array}$ & $\begin{array}{c}\text { Total Area } \\
\left(\mathbf{m}^{\mathbf{2}}\right)\end{array}$ & $\begin{array}{c}\text { Floor Area } \\
\left(\mathbf{m}^{\mathbf{2}}\right)\end{array}$ \\
\hline Studio room & 32.0 & 63 & 13 \\
Control room & 12.3 & 39 & 6 \\
\hline
\end{tabular}

Some pictures of the studio room are presented in Figure 11 and photographs of the control room in Figure 12.
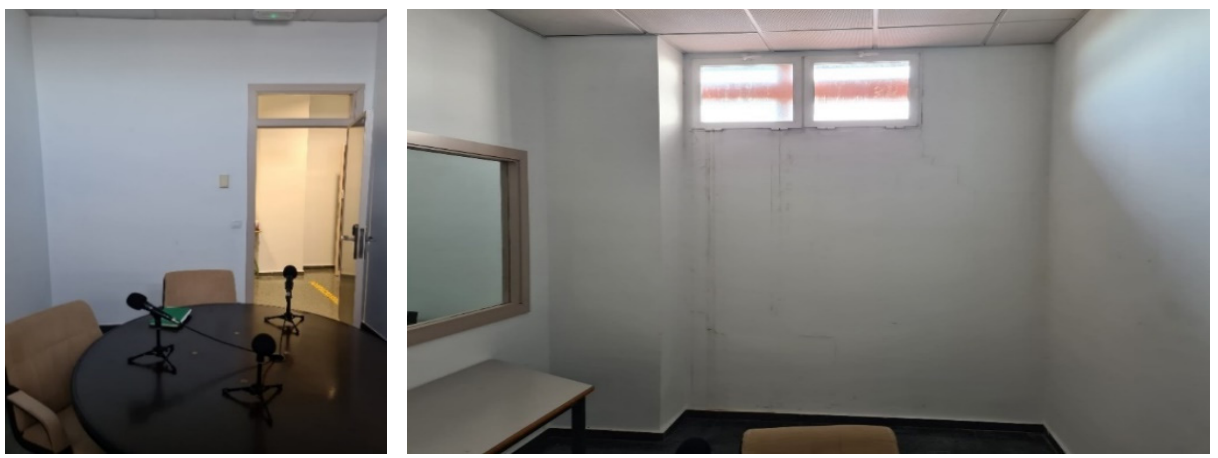

Figure 11. The initial state of the studio room. 

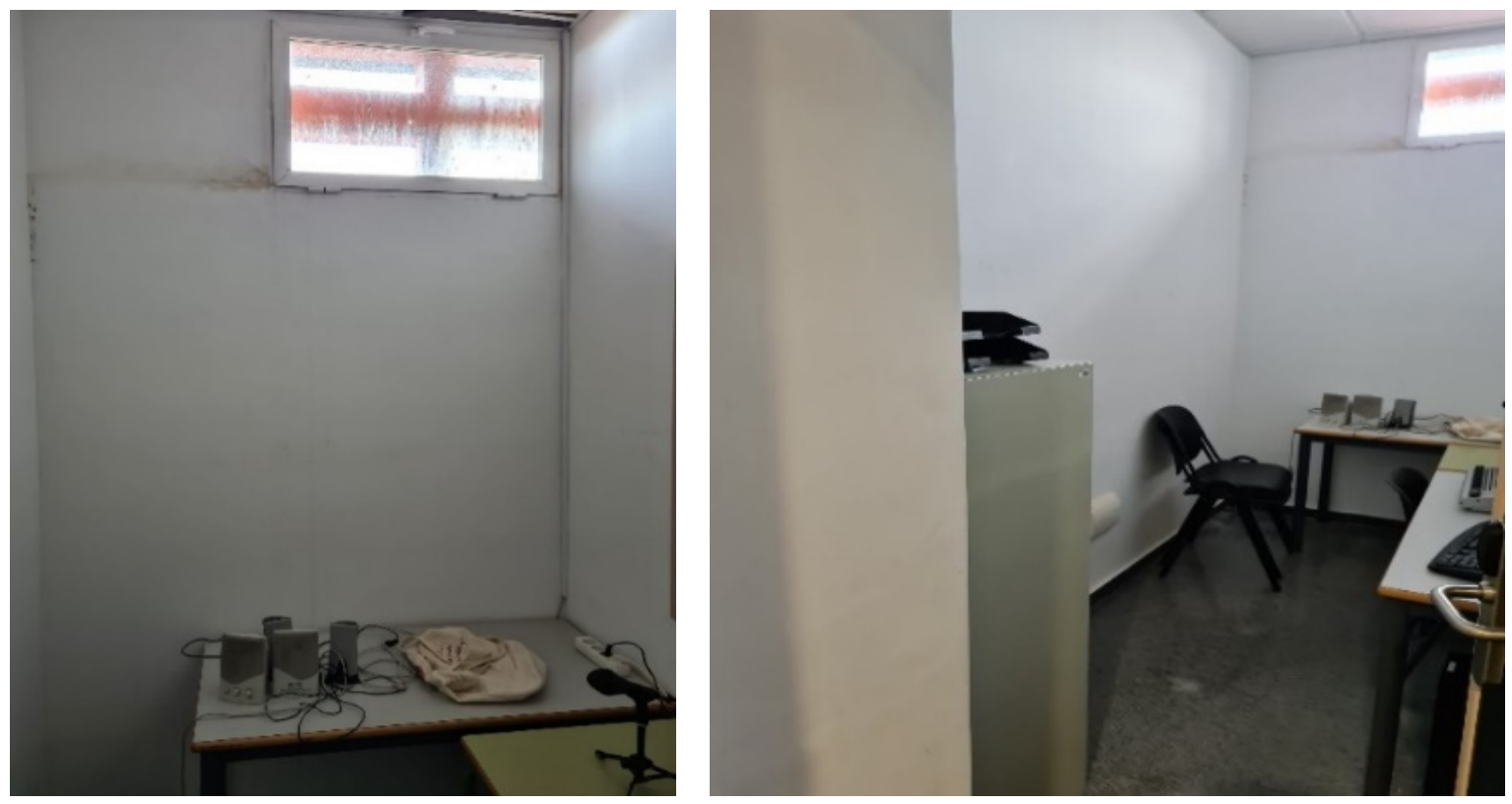

Figure 12. The initial state of the control room.

\subsection{Initial State of the Studio Rooms}

The first stage of the project consisted of analyzing the initial acoustical conditions of the enclosures, for which two types of studies were carried out: sound insulation and acoustic conditioning. The tests and the results for each case are described in the following sections.

\subsubsection{Sound Insulation}

The airborne sound insulation of the two most critical vertical partitions was evaluated according to the ISO 16283-1 standard [46]. The standardized difference level, $\mathrm{D}_{\mathrm{nT}}$, was obtained from the measurements in one-third octave bands. Then the weighted values were calculated from the one-third octave band measurements by following the ISO 717-1 [47] for the $D_{n T, w}$ and the DB-HR [41] for the $D_{n T, A}$. The weighted values help to rate the sound insulation levels in buildings.

The assessed vertical partitions were:

- The vertical partition between the stairs and the studio room: the corridor stairs were taken as the source enclosure and the studio room as the receiving enclosure. We were interested in the incoming noise levels received in the studio room from the common area.

- The vertical partition between the toilets and the control room: the bathroom was taken as the source enclosure and the control room as the receiving enclosure. In this case, we were interested in knowing the incoming noise levels received in the control room coming from the toilets.

The rest of the vertical partitions were not analyzed due to the existence of doors or windows, which would not have allowed us to check the performance of the proposed solution.

The graph in Figure 13 represents the standardized level difference values, $\mathrm{D}_{\mathrm{nT}}$, in one-third octave bands obtained during the in-situ measurements.

Table 8 shows the weighted standardized level difference values, $\mathrm{D}_{\mathrm{nT}, \mathrm{w}}$, for each assessed partition (also in A-weighting, $\mathrm{D}_{\mathrm{nT}, \mathrm{A}}$ ). 


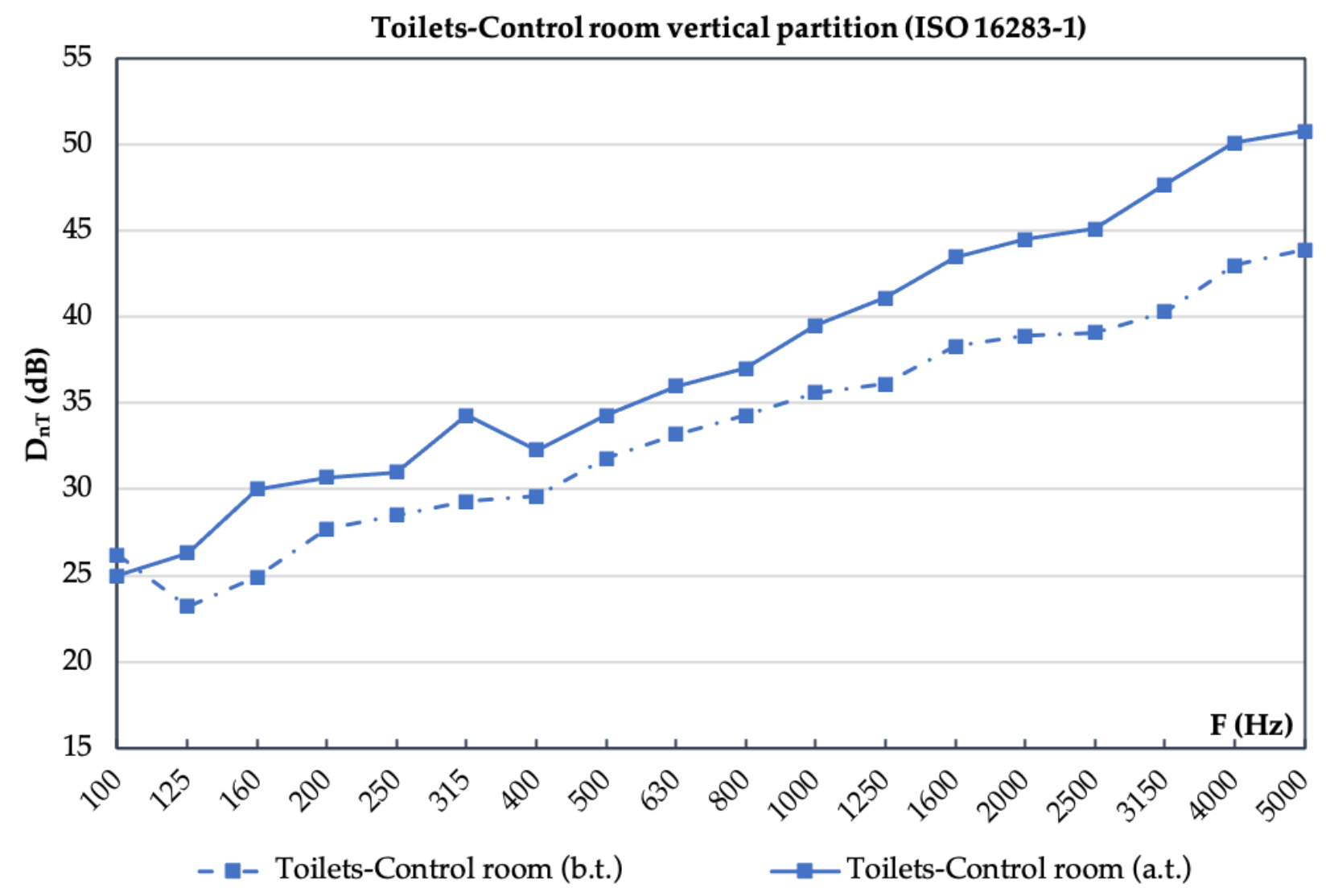

Figure 13. Standardized level difference from the initial measurement of the vertical partitions.

Table 8. Weighted standardized level difference values of the vertical partitions.

\begin{tabular}{ccc}
\hline & Stairs-Studio Room & Toilets-Control Room \\
\hline $\mathrm{D}_{\mathrm{nT}, \mathrm{A}}(\mathrm{dBA})$ & 35.9 & 35.6 \\
$\mathrm{D}_{\mathrm{nT}, \mathrm{w}}(\mathrm{dB})$ & 36.3 & 36.0 \\
\hline
\end{tabular}

The obtained values reflect the need to implement some kind of sound insulation treatment in these partitions.

\subsubsection{Acoustic Conditioning}

The acoustic conditioning of the enclosures was evaluated by measuring the reverberation time with the interrupted noise method, following the guidelines of the ISO 3382-2 standard [2]. The integrated impulse response of the rooms was also used to calculate the typical acoustic quality parameters. Although most of these parameters are usually evaluated with occupied room conditions, they were used as a reference to estimate the acoustic behavior of the rooms.

The initial values obtained for the reverberation time in octave bands are represented in Figure 14.

The results obtained for the acoustical parameters in unoccupied room conditions are presented in Table 9. Values are compared to desirable target values for speech and studio rooms.

As shown in Table 9, the results obtained for the parameters show that not all the target values were met. The average reverberation time $\left(\mathrm{RT}_{\mathrm{mid}}\right)$ is high relative to the recommended value and, consequently, the definition (D) is also high. Although the STI is already over the defined objective, the closer to 1 in the studio room, the better since it is a dedicated speech room. 


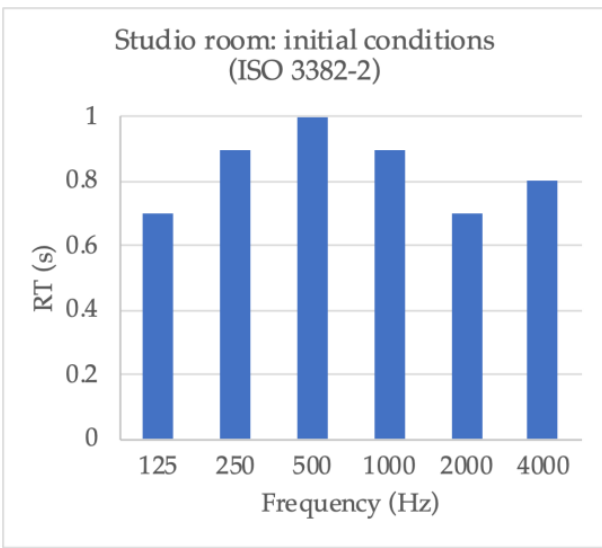

(a)

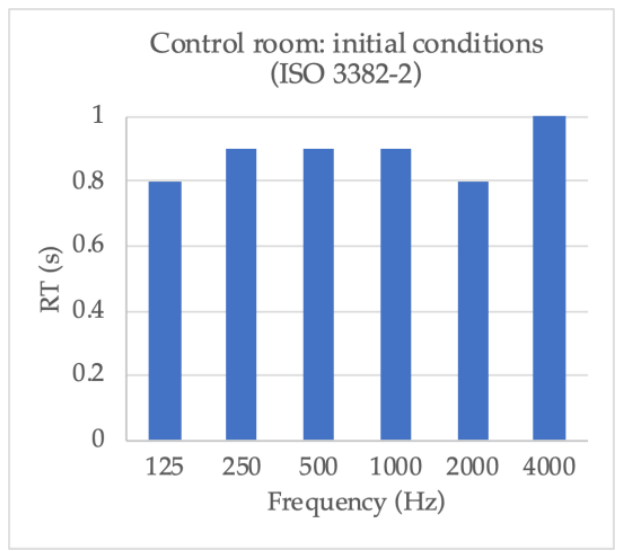

(b)

Figure 14. The initial reverberation time of the enclosures: (a) studio room; (b) control room.

Table 9. Measured parameters of the enclosures under study.

\begin{tabular}{cccc}
\hline Acoustical Parameter & $\begin{array}{c}\text { Studio Room } \\
\text { (Unoccupied) }\end{array}$ & $\begin{array}{c}\text { Control Room } \\
\text { (Unoccupied) }\end{array}$ & $\begin{array}{c}\text { Target Value } \\
\text { (Occupied) }\end{array}$ \\
\hline $\begin{array}{c}\mathrm{RT}_{\text {mid }}(\mathrm{s}), \\
(500 \mathrm{~Hz}-1 \mathrm{kHz})\end{array}$ & 0.9 & 1.0 & $0.2 \leq \mathrm{RT}_{\text {mid }} \leq 0.4$ \\
\hline $\mathrm{STI}$ & 0.72 & 0.73 & $\mathrm{STI} \geq 0.60$ \\
\hline $\begin{array}{c}\mathrm{C}_{50}(\mathrm{~dB}), \\
(500 \mathrm{~Hz}-4 \mathrm{kHz})\end{array}$ & 3.8 & 4.5 & $>2 \mathrm{~dB}$ \\
\hline $\begin{array}{c}\text { Definition, D, } \\
(125 \mathrm{~Hz}-4 \mathrm{kHz})\end{array}$ & 0.30 & 0.33 & $\mathrm{D}>0.50$ \\
\hline
\end{tabular}

\subsection{Acoustic Treatment}

The multifunctional solution proposed in this work was perfect for this project since it allowed us to treat sound insulation and acoustic conditioning problems at once.

From the results of the four different configurations previously assessed (presented in Section 3.1), it can be seen that each of the four perforated plasterboard lining configurations provide different benefits, so a combination of them was used according to the needs of each room and vertical partition. Figure 15 shows the distribution of the perforated plasterboards, detailed in Table 1, over the base walls.

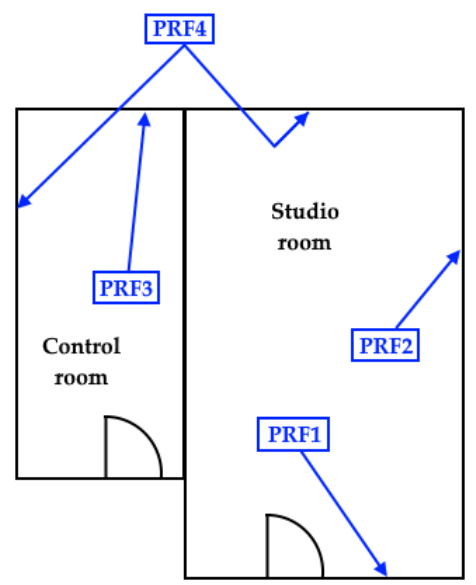

Figure 15. Distribution of the different perforated plasterboards over the rooms. 
The PB + VLM + PRF4 was used in the wall between the toilets and the control room vertical partition. Despite not being the best for sound insulation, this partition required a high degree of absorption since the loudspeakers of the control room were going to be located in the front wall, which also contains the window between the two rooms, so it is highly reflective. In the case of the wall between the stairs and the studio room, the PB + $\mathrm{VLM}+$ PRF2 configuration has been used. In this case, the selection was mainly dictated by its better properties for sound insulation since sound absorption was not so critical in this room.

Some pictures of the rooms after installing the different configurations of the proposed solution can be seen in Figure 16.

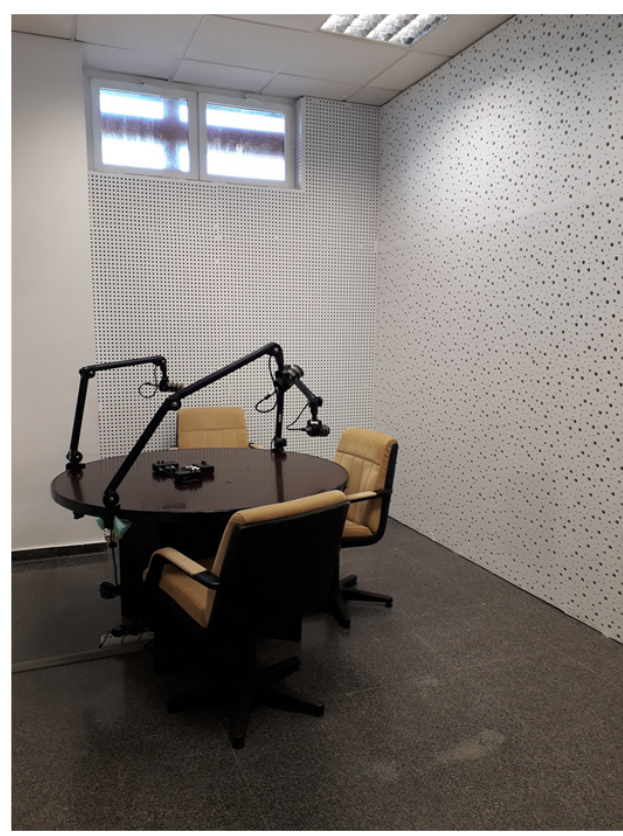

(a)

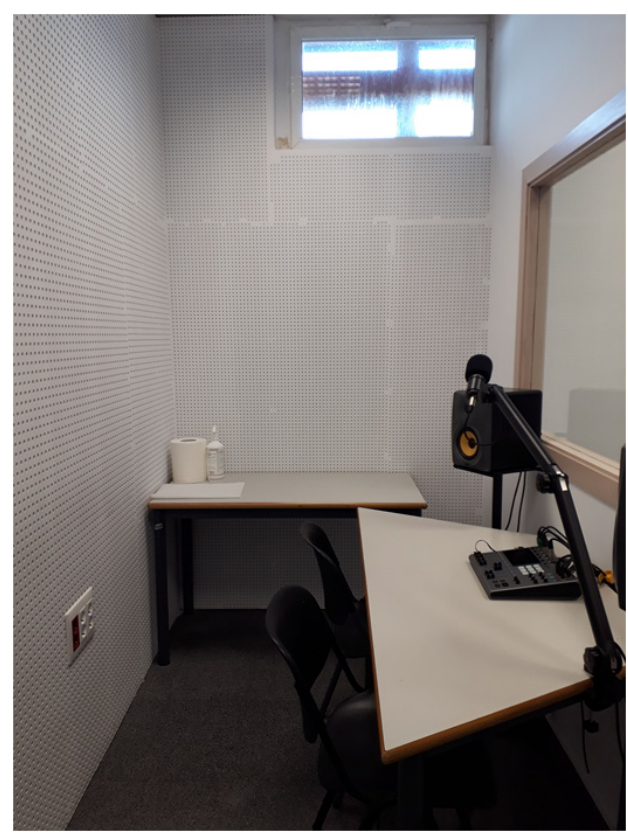

(b)

Figure 16. Images of the rooms with the proposed multifunctional solution installed: (a) studio room; (b) control room.

\subsection{Acoustic Behavior after Treatment}

\subsubsection{Sound Insulation}

The comparison between the results for the standardized level difference before and after applying the proposed solution in the stairs-studio room vertical partition is presented in Figure 17. It can be affirmed that in almost every one-third octave band, especially in medium and high frequencies, the proposed solution improves the standardized level difference of the treated wall.

Table 10 presents the values of the standardized weighted level difference $D_{n T, w}$ and also the A-weighted version, $\mathrm{D}_{\mathrm{nT}, \mathrm{A}}$, before and after the acoustic treatment. As can be seen, the installed solution provided a $6 \mathrm{~dB}$ improvement in sound insulation in the weighted values.

The comparison between the results for the standardized level difference before and after by applying the proposed solution in the stairs-studio room vertical partition is presented in Figure 18. Again, it can be seen that the proposed solution improves the sound insulation in almost every one-third octave band. 


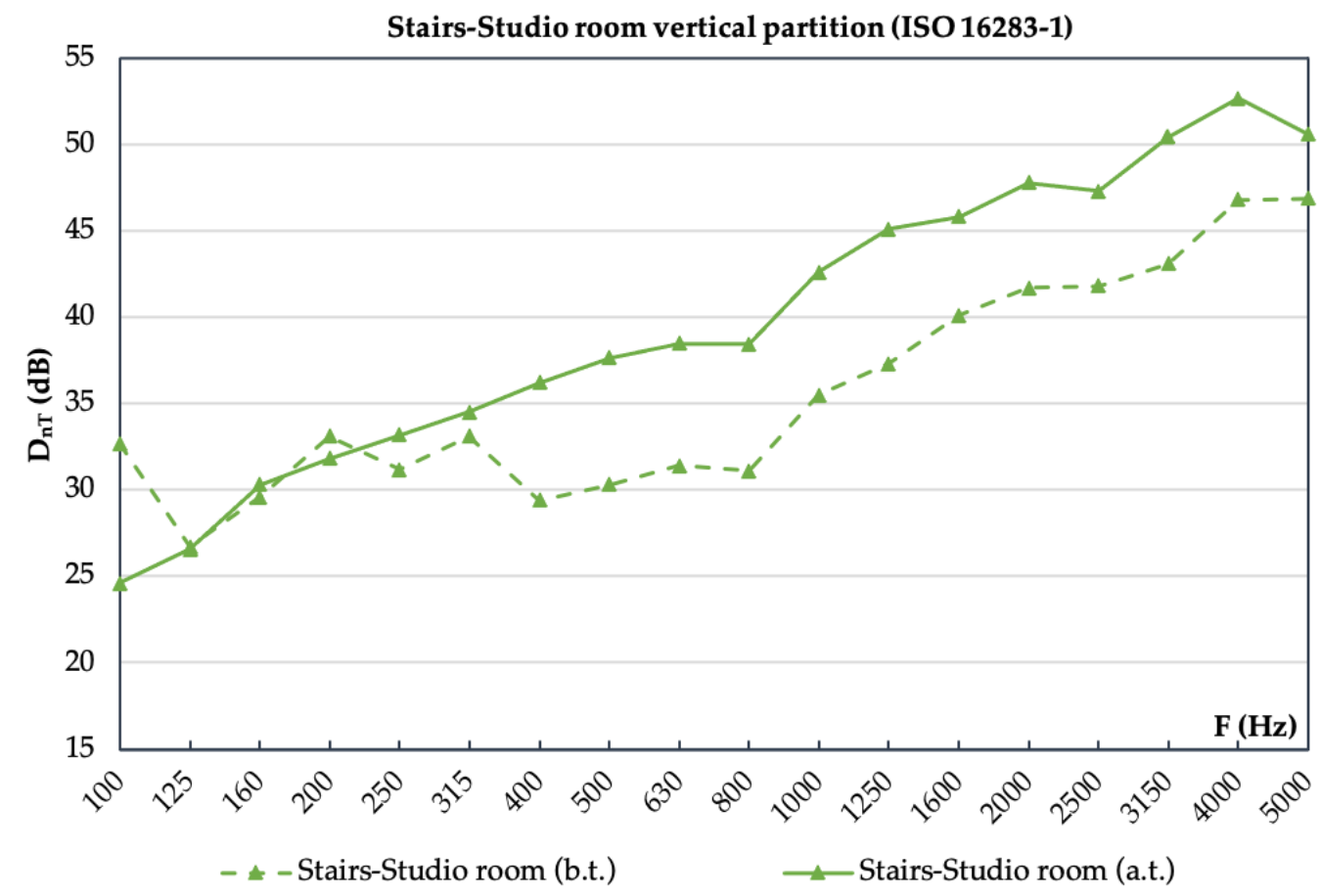

Figure 17. Standardized level difference of the stairs-studio room vertical partition.

Table 10. Weighted standardized level difference values for the stairs-studio room vertical partition, before and after treatment.

\begin{tabular}{cccc}
\hline & Before Treatment & After Treatment & Improvement \\
\hline $\mathrm{D}_{\mathrm{nT}, \mathrm{A}}(\mathrm{dBA})$ & 35.9 & 41.4 & 5.5 \\
$\mathrm{D}_{\mathrm{nT}, \mathrm{w}}(\mathrm{dB})$ & 36.3 & 42.3 & 6.0 \\
\hline
\end{tabular}

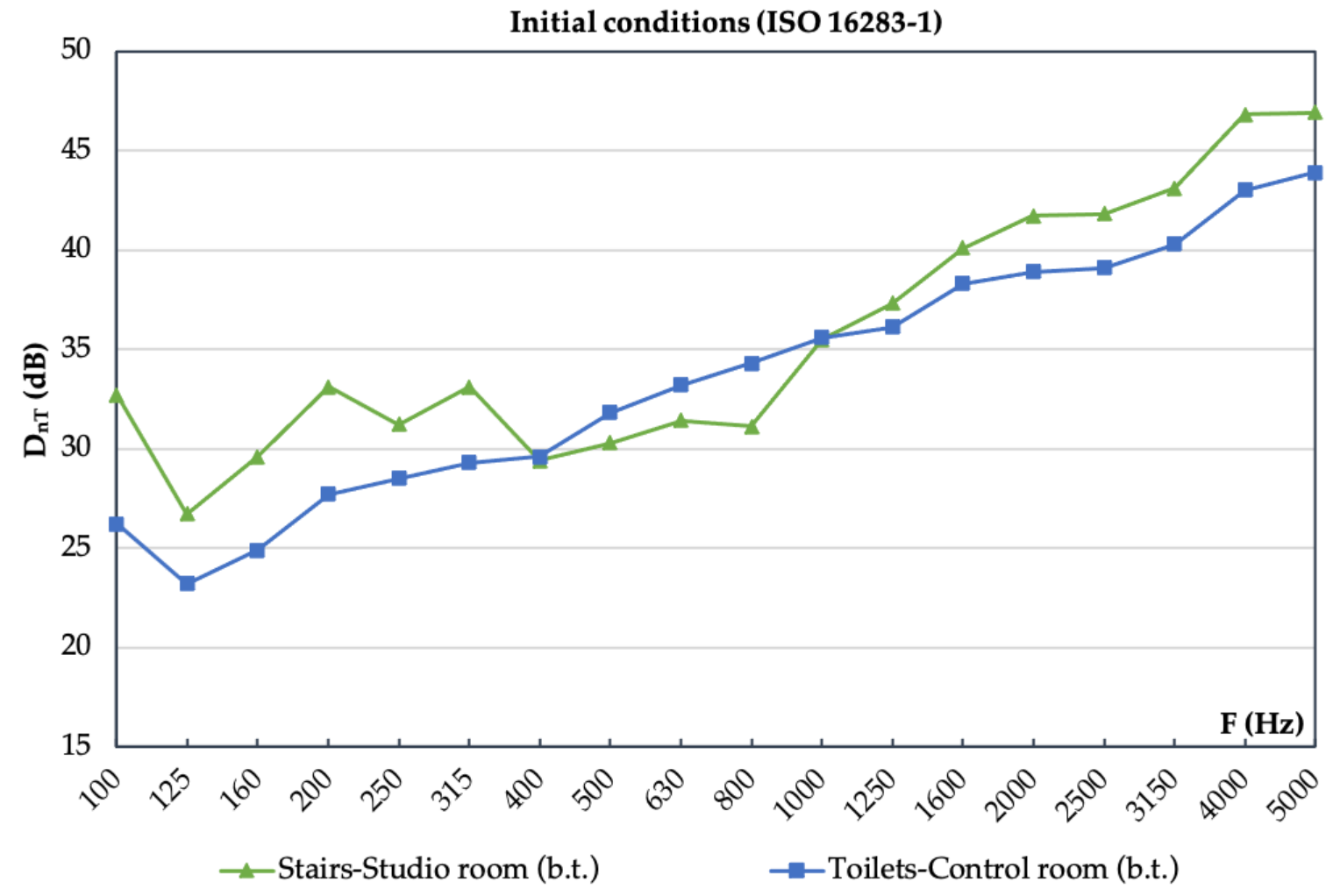

Figure 18. Standardized level difference of the toilets-control room vertical partition. 
In this case, as expected, the sound insulation improvement is lower than in the previous one. As shown in Table 11, there is an improvement of almost $4 \mathrm{~dB}$ in the weighted standardized level difference values after applying the acoustic treatment.

Table 11. Weighted standardized level difference values for the toilets-control room vertical partition, before and after treatment.

\begin{tabular}{cccc}
\hline & Before Treatment & After Treatment & Improvement \\
\hline $\mathrm{D}_{\mathrm{nT}, \mathrm{A}}(\mathrm{dBA})$ & 35.6 & 39.3 & 3.7 \\
$\mathrm{D}_{\mathrm{nT}, \mathrm{w}}(\mathrm{dB})$ & 36.0 & 39.8 & 3.8 \\
\hline
\end{tabular}

\subsubsection{Acoustic Conditioning}

To validate the proposed solution, the same in-situ measurements were made as in the assessment of the initial condition of the rooms. The final values obtained for the reverberation time in octave bands are represented in Figure 19. As can be seen in the results, the reverberation time was reduced considerably. It is expected to be reduced a little bit more, especially in mid and high frequencies, when the rooms are populated with people and furniture. Control room compliance was not validated according to the EBU Tech 3276 recommendations [48] since it was not the objective of this work. Nevertheless, the room was left in optimal conditions to comply with them.

Studio room: before vs after treatment

(ISO 3382-2)

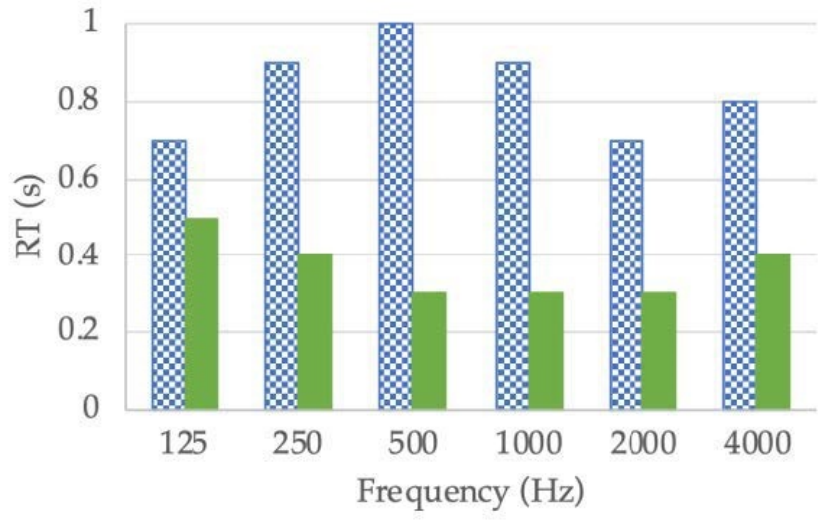

B Before treatment $\boxminus$ After treatment
Control room: before vs after treatment (ISO 3382-2)

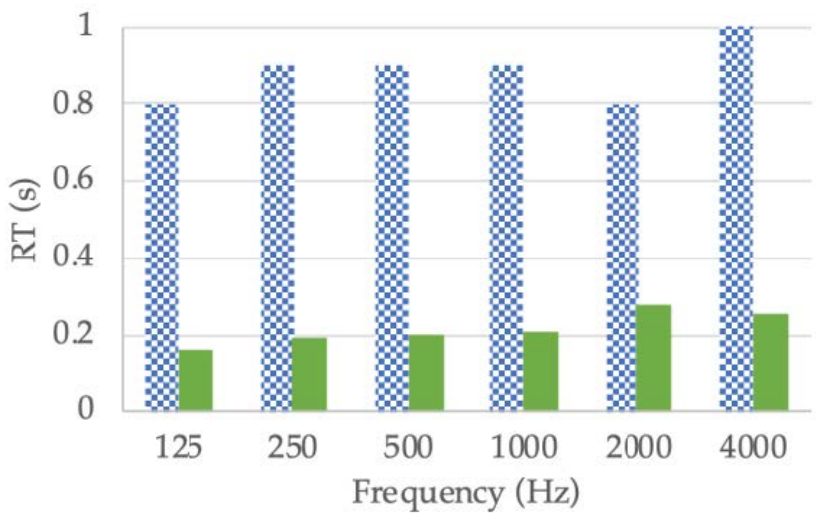

x Before treatment $\quad$ After treatment

(b)

Figure 19. The final reverberation time of the rooms: (a) studio room; (b) control room.

A comparison of the acoustic parameter values obtained before and after the acoustic treatment is presented in Table 12.

The average reverberation time ( $\left.\mathrm{RT}_{\text {mid }}\right)$ decreased compared to the initial state, and with it, the rest of the acoustic quality parameters also improved considerably. This is due to the perforated plasterboards and the highly absorbent textile felt of the viscoelastic multilayer material used in the plenum. 
Table 12. Comparison of the acoustic parameters of the rooms.

\begin{tabular}{cccccc}
\hline Parameter & \multicolumn{2}{c}{$\begin{array}{c}\text { Studio Room } \\
\text { (Unoccupied) }\end{array}$} & \multicolumn{2}{c}{$\begin{array}{c}\text { Control Room } \\
\text { (Unoccupied) }\end{array}$} & $\begin{array}{c}\text { Target Value } \\
\text { (Occupied) }\end{array}$ \\
\hline & $\begin{array}{c}\text { Before } \\
\text { Treat. }\end{array}$ & $\begin{array}{c}\text { After } \\
\text { Treat. }\end{array}$ & $\begin{array}{c}\text { Before } \\
\text { Treat. }\end{array}$ & $\begin{array}{c}\text { After } \\
\text { Treat. }\end{array}$ & \\
\hline $\begin{array}{c}\mathrm{RT}_{\text {mid }}(\mathrm{s}), \\
(500 \mathrm{~Hz}-1 \mathrm{kHz})\end{array}$ & 0.9 & 0.3 & 1.0 & 0.2 & $0.2 \leq \mathrm{RT}_{\text {mid }} \leq 0.4$ \\
\hline $\mathrm{STI}$ & 0.72 & 0.91 & 0.73 & 0.91 & $\geq 0.60$ \\
\hline $\begin{array}{c}\mathrm{C}_{50}(\mathrm{~dB}), \\
(500 \mathrm{~Hz}-4 \mathrm{kHz})\end{array}$ & 3.8 & 15.2 & 4.5 & 19.5 & $>2$ \\
\hline $\begin{array}{c}\text { Definition, D, } \\
(125 \mathrm{~Hz}-4 \mathrm{kHz})\end{array}$ & 0.30 & 0.97 & 0.30 & 0.99 & $>0.50$ \\
\hline
\end{tabular}

\section{Discussion}

A multifunctional solution that can be used to improve sound insulation and acoustic conditioning simultaneously has been presented. This means a significant saving in installation costs.

Four different configurations have been assessed, each one with different aesthetics (perforation rates, sizes and shapes), yielding results of direct application to the market.

It has been proven that the combination of the viscoelastic multilayer with the perforated plates can be used for acoustic conditioning, yielding values over 0.5 for the sound absorption coefficient in all the interest range for building acoustics. The higher values were reached with perforation rates between $16-18 \%$ and diameters or square sides of $12 \mathrm{~mm}$. These results could be tuned by making controlled changes in the air plenum or the perforation rate and size.

It has also been proven that besides the excellent performance for acoustic conditioning, the solution also provides good levels of improvement in noise reduction. It is foreseeable that some of these levels of improvement could be increased with some adjustments in the viscoelastic multilayer. The increase of the mass density of the viscoelastic membrane would increase the levels of improvement in noise reduction, and the increase in the thickness of the textile felt would improve the sound absorption of the complete solution. However, it has to be taken into account that these changes require an analysis to find a good compromise between the modifications and the improvements provided by them. Therefore, these studies are left for future works.

Finally, two small enclosures with unfavorable acoustic conditioning and sound insulation conditions were treated with the proposed multifunctional solution to function as a radio studio. The poor initial acoustic conditions were revealed during the analysis of the initial in-situ measurements. After treating the rooms with the proposed multifunctional solution, improvements between 4 and $6 \mathrm{~dB}$ in the weighted standardized difference levels were obtained, and the acoustic quality parameters also improved considerably.

This study shows that these two usual acoustic problems in building acoustics can be addressed with the same solution.

Author Contributions: Conceptualization, J.A.; methodology, J.A.; validation, J.A., R.d.R. and J.C.R.; formal analysis, J.A.; investigation, J.A. and J.C.R.; resources, J.A. and R.d.R.; data curation, J.C.R.; writing—original draft preparation, J.C.R.; writing-review and editing, J.A., R.d.R. and J.C.R.; supervision, J.A.; project administration, J.A. and R.d.R.; funding acquisition, J.A. and R.d.R. All authors have read and agreed to the published version of the manuscript. 
Funding: This work is included within the project IMINOA/2019/110: DESARROLLO DE SISTEMA DE AISLAMIENTO Y ACONDICIONAMIENTO ACÚSTICO, through the program PROYECTOS DE INNOVACIÓN DE PYME (INNOVA-CV), in the action INNOVACIÓN PYME. INNOVACIÓN DE PRODUCTO (INNOVAProD-CV) of the Institut Valencià de Competitivitat Empresarial (IVACE). It has also been financially supported by the Conselleria de Innovación, Universidades, Ciencia y Sociedad - Generalitat Valenciana, through the ACIF-2020 program (grant number ACIF/2020/401), and the European Social Fund.

Conflicts of Interest: The authors declare no conflict of interest.

\section{References}

1. Kuerer, R.C. Classes of Acoustical Comfort in Housing: Improved Information about Noise Control in Buildings. Appl. Acoust. 2002, 52, 197-210. [CrossRef]

2. Huang, L.; Zhu, Y.; Ouyang, Q.; Cao, B. A Study on the Effects of Thermal, Luminous, and Acoustic Environments on Indoor Environmental Comfort in Offices. Build. Environ. 2012, 49, 304-309. [CrossRef]

3. Hongisto, V.; Mäkilä, M.; Suokas, M. Satisfaction with Sound Insulation in Residential Dwellings-The Effect of Wall Construction. Build. Environ. 2015, 85, 309-320. [CrossRef]

4. Rychtáriková, M.; Muellner, H.; Chmelík, V.; Roozen, N.B.; Urbán, D.; Garcia, D.P.; Glorieux, C. Perceived Loudness of Neighbour Sounds Heard Through Heavy and Light-Weight Walls with Equal Rw + C50-5000. Acta Acust. United Acust. 2016, 102, 58-66. [CrossRef]

5. Alonso, A.; Patricio, J.; Suárez, R.; Escandón, R. Acoustical Retrofit of Existing Residential Buildings: Requirements and Recommendations for Sound Insulation between Dwellings in Europe and Other Countries Worldwide. Build. Environ. 2020, 174, 10677. [CrossRef]

6. Liao, G.; Luan, C.; Wang, Z.; Liu, J.; Yao, X.; Fu, J. Acoustic Metamaterials: A Review of Theories, Structures, Fabrication Approaches, and Applications. Adv. Mater. Technol. 2021, 6, 1-29. [CrossRef]

7. Kumar, S.; Lee, H. The Present and Future Role of Acoustic Metamaterials for Architectural and Urban Noise Mitigations. Acoustics 2019, 1, 590-607. [CrossRef]

8. Beranek, L.L.; Work, G.A. Sound Transmission through Multiple Structures Containing Flexible Blankets. J. Acoust. Soc. Am. 1949, 21, 419-428. [CrossRef]

9. Alba, J.; Marant, V.; Aguilera, J.L.; Ramis, J.; del Rey, R. Technical Note: Prediction Models of Airborne Sound Insulation of Multilayer Materials with Viscoelastic Thin Sheets. Build. Acoust. 2008, 15, 325-334. [CrossRef]

10. Rubino, C.; Bonet Aracil, M.; Gisbert-Payá, J.; Liuzzi, S.; Stefanizzi, P.; Zamorano Cantó, M.; Martellotta, F. Composite Eco-Friendly Sound Absorbing Materials Made of Recycled Textile Waste and Biopolymers. Materials 2019, 12, 4020. [CrossRef]

11. Padhye, R.; Nayak, R. Acoustic Textiles. Textile Science and Clothing Technology; Springer: Melbourne, Australia, 2016.

12. Seddeq, H.S.; Aly, N.M.; Marwa, A.A.; Elshakankery, M.H. Investigation on Sound Absorption Properties for Recycled Fibrous Materials. J. Ind. Text. 2013, 43, 56-73. [CrossRef]

13. Arenas, J.P.; Sakagami, K. Sustainable Acoustic Materials. Sustainability 2020, 12, 6540. [CrossRef]

14. Arenas, J.P.; del Rey, R.; Alba, J.; Oltra, R. Sound-Absorption Properties of Materials Made of Esparto Grass Fibers. Sustainability 2020, 12, 5533. [CrossRef]

15. Parlato, M.C.M.; Porto, S.M.C. Organized Framework of Main Possible Applications of Sheep Wool Fibers in Building Components. Sustainability 2020, 12, 761. [CrossRef]

16. Arenas, J.P.; Asdrubali, F. Eco-Materials with Noise Reduction Properties. In Handbook of Ecomaterials; Springer International Publishing: Cham, Switzerland, 2019; Volume 5, pp. 3031-3056. [CrossRef]

17. Buratti, C.; Belloni, E.; Lascaro, E.; Merli, F.; Ricciardi, P. Rice Husk Panels for Building Applications: Thermal, Acoustic and Environmental Characterization and Comparison with Other Innovative Recycled Waste Materials. Constr. Build. Mater. 2018, 171, 338-349. [CrossRef]

18. del Rey, R.; Berto, L.; Alba, J.; Arenas, J.P. Acoustic Characterization of Recycled Textile Materials Used as Core Elements in Noise Barriers. Noise Control Eng. J. 2015, 63, 439-447. [CrossRef]

19. Asdrubali, F.; Schiavoni, S.; Horoshenkov, K.V. A Review of Sustainable Materials for Acoustic Applications. Build. Acoust. 2012, 19, 283-312. [CrossRef]

20. Pereira, A.; Gaspar, A.; Mendes, P.A.; Mateus, D.; Carbajo, J.; Ramis, J.; Poveda, P. On the Use of Perforated Sound Absorption Systems for Variable Acoustics Room Design. Buildings 2021, 11, 543. [CrossRef]

21. Cucharero, J.; Hänninen, T.; Makkonen, M.; Lokki, T. Acoustic Coatings-A Discreet Way to Control Acoustic Environment. Front. Built Environ. 2021, 7, 665332. [CrossRef]

22. ISO 12354-1:2017. Building Acoustics-Estimation of Acoustic Performance of Buildings from the Performance of Elements-Part 1: Airborne Sound Insulation between Rooms; International Organization for Standardization: Geneva, Switzerland, 2017.

23. ISO 9053-1:2018. Acoustics-Determination of Airflow Resistance-Part 1: Static Airflow Method; International Organization for Standardization: Geneva, Switzerland, 2018. 
24. ISO 9053-2:2020. Acoustics—Determination of Airflow Resistance-Part 2: Alternating Airflow Method; International Organization for Standardization: Geneva, Switzerland, 2020.

25. ASTM C522-03. Standard Test Method for Airflow Resistance of Acoustical Materials; ASTM International: West Conshohocken, PA, USA, 2016. [CrossRef]

26. Stinson, M.R.; Daigle, G.A. Electronic System for the Measurement of Flow Resistance. J. Acoust. Soc. Am. 1988, 83, 2422-2428. [CrossRef]

27. Ingard, K.U.; Dear, T.A. Measurement of Acoustic Flow Resistance. J. Sound Vib. 1985, 103, 567-572. [CrossRef]

28. Woodcock, R.; Hodgson, M. Acoustic Methods for Determining the Effective Flow Resistivity of Fibrous Materials. J. Sound Vib. 1992, 153, 186-191. [CrossRef]

29. Ren, M.; Jacobsen, F. A Method of Measuring the Dynamic Flow Resistance and Reactance of Porous Materials. Appl. Acoust. 1993, 39, 265-276. [CrossRef]

30. Picard, M.A.; Solana, P.; Urchueguía, J.F. A Method of Measuring the Dynamic Flow Resistance and the Acoustic Measurement of the Effective Static Flow Resistance in Stratified Rockwool Samples. J. Sound Vib. 1998, 216, 495-505. [CrossRef]

31. Sebaa, N.; Fellah, Z.E.A.; Fellah, M.; Lauriks, W.; Depollier, C. Measuring Flow Resistivity of Porous Material via Acoustic Reflected Waves. J. Appl. Phys. 2005, 98, 084901. [CrossRef]

32. Panneton, R.; Olny, X. Acoustical Determination of the Parameters Governing Viscous Dissipation in Porous Media. J. Acoust. Soc. Am. 2006, 119, 2027-2040. [CrossRef]

33. Doutres, O.; Salissou, Y.; Atalla, N.; Panneton, R. Evaluation of the Acoustic and Non-Acoustic Properties of Sound Absorbing Materials Using a Three-Microphone Impedance Tube. Appl. Acoust. 2010, 71, 506-509. [CrossRef]

34. Dragonetti, R.; Ianniello, C.; Romano, R.A. Measurement of the Resistivity of Porous Materials with an Alternating Air-Flow Method. J. Acoust. Soc. Am. 2011, 129, 753-764. [CrossRef]

35. Alba, J.; Arenas, J.P.; del Rey, R.; Rodríguez, J.C. An Electroacoustic Method for Measuring Airflow Resistivity of Porous Sound-Absorbing Materials. Appl. Acoust. 2019, 150, 132-137. [CrossRef]

36. ISO 10140-2:2021. Acoustics_Laboratory Measurement of Sound Insulation of Building Elements_Part 2: Measurement of Airborne Sound Insulation; International Organization for Standardization: Geneva, Switzerland, 2021.

37. ISO 10140-4:2021. Acoustics_Laboratory Measurement of Sound Insulation of Building Elements_Part 4: Measurement Procedures and Requirements; International Organization for Standardization: Geneva, Switzerland, 2021.

38. ISO 10140-5:2021. Acoustics_Laboratory Measurement of Sound Insulation of Building Elements—Part 5: Requirements for Test Facilities and Equipment; International Organization for Standardization: Geneva, Switzerland, 2021.

39. Godinho, L.; Masgalos, R.; Pereira, A.; Branco, F.G. On the Use of a Small-Sized Acoustic Chamber for the Analysis of Impact Sound Reduction by Floor Coverings. Noise Control Eng. J. 2010, 58, 658-668. [CrossRef]

40. del Rey, R.; Alba, J.; Rodríguez, J.C.; Bertó, L. Characterization of New Sustainable Acoustic Solutions in a Reduced Sized Transmission Chamber. Buildings 2019, 9, 60. [CrossRef]

41. Ministerio de Fomento de España. Documento Básico HR Protección Frente al Ruido (DB-HR). Available online: https://www. codigotecnico.org/images/stories/pdf/proteccionRuido/DccHR.pdf (accessed on 20 December 2021).

42. España. REAL DECRETO 314/2006, de 17 de Marzo, Por El Que Se Aprueba El Código Técnico de La Edificación. Boletín Oficial del Estado. 28 March 2006, pp. 11816-11831. Available online: https://noticias.juridicas.com/base_datos/Admin/rd314-2006.html (accessed on 10 November 2021).

43. ISO 354:2003. Acoustics-Measurement of Sound Absorption in a Reverberation Room; International Organization for Standardization: Geneva, Switzerland, 2003.

44. ISO 11654:1997. Acoustics—Sound Absorbers for Use in Buildings_Rating of Sound Absorption; International Organization for Standardization: Geneva, Switzerland, 1997.

45. ASTM C423-17. Standard Test Method for Sound Absorption and Sound Absorption Coefficients by the Reverberation Room Method; ASTM International: West Conshohocken, PA, USA, 2017.

46. ISO 16283-1:2014. Acoustics_Field Measurement of Sound Insulation in Buildings and of Building Elements—Part 1: Airborne Sound Insulation; International Organization for Standardization: Geneva, Switzerland, 2014.

47. ISO 717-1:2013. Acoustics-Rating of Sound Insulation in Buildings and of Building Elements-Part 1: Airborne Sound Insulation; International Organization for Standardization: Geneva, Switzerland, 2013.

48. European Broadcasting Union. EBU Tech. 3276-Listening Conditions for the Assessment of Sound Programme Material: Monophonic and Two-Channel Stereophonic, 2nd ed.; Grand-Saconnex: Geneva, Switzerland, 1998; Volume 3276. 